\title{
Microcystis Sp. Co-Producing Microcystin and Saxitoxin from Songkhla Lake Basin, Thailand
}

\author{
Ampapan Naknaen ${ }^{1}$, Waraporn Ratsameepakai ${ }^{2}$, Oramas Suttinun ${ }^{1,3}$, Yaowapa Sukpondma ${ }^{4}$, Eakalak Khan ${ }^{5}$ D \\ and Rattanaruji Pomwised $6, *$ (D)
}

1 Environmental Assessment and Technology for Hazardous Waste Management Research Center, Faculty of Environmental Management, Prince of Songkla University, Hat Yai 90110, Thailand; ampapan.nk@gmail.com (A.N.); oramas.s@psu.ac.th (O.S.)

2 Office of Scientific Instrument and Testing, Prince of Songkla University, Hat Yai 90110, Thailand; waraporn.ra@psu.ac.th

3 Center of Excellence on Hazardous Substance Management (HSM), Bangkok 10330, Thailand

4 Division of Physical Science, Faculty of Science, Prince of Songkla University, Hat Yai 90110, Thailand; yaowapa.suk@psu.ac.th

5 Department of Civil and Environmental Engineering and Construction, University of Nevada, Las Vegas, NV 89154-4015, USA; eakalak.khan@unlv.edu

6 Division of Biological Science, Faculty of Science, Prince of Songkla University, Hat Yai 90110, Thailand

* Correspondence: rattanaruji.p@psu.ac.th; Tel.: +66-74-288-325

Citation: Naknaen, A.;

Ratsameepakai, W.; Suttinun, O.; Sukpondma, Y.; Khan, E.; Pomwised, R. Microcystis Sp. Co-Producing Microcystin and Saxitoxin from Songkhla Lake Basin, Thailand. Toxins 2021, 13, 631. https:// doi.org/10.3390/toxins13090631

Received: 29 July 2021

Accepted: 3 September 2021

Published: 8 September 2021

Publisher's Note: MDPI stays neutral with regard to jurisdictional claims in published maps and institutional affiliations.

\section{Copyright: (c) 2021 by the authors.} Licensee MDPI, Basel, Switzerland. This article is an open access article distributed under the terms and conditions of the Creative Commons Attribution (CC BY) license (https:// creativecommons.org/licenses/by/ $4.0 /)$.

\begin{abstract}
The Songkhla Lake Basin (SLB) located in Southern Thailand, has been increasingly polluted by urban and industrial wastewater, while the lake water has been intensively used. Here, we aimed to investigate cyanobacteria and cyanotoxins in the SLB. Ten cyanobacteria isolates were identified as Microcystis genus based on16S rDNA analysis. All isolates harbored microcystin genes, while five of them carried saxitoxin genes. On day 15 of culturing, the specific growth rate and Chl- $a$ content were $0.2-0.3$ per day and $4 \mu \mathrm{g} / \mathrm{mL}$. The total extracellular polymeric substances (EPS) content was $0.37-0.49 \mu \mathrm{g} / \mathrm{mL}$. The concentration of soluble EPS (sEPS) was 2 times higher than that of bound EPS (bEPS). The protein proportion in both sEPS and bEPS was higher than the carbohydrate proportion. The average of intracellular microcystins (IMCs) was $0.47 \mathrm{pg} /$ cell on day 15 of culturing, while extracellular microcystins (EMCs) were undetectable. The IMCs were dramatically produced at the exponential phase, followed by EMCs release at the late exponential phase. On day 30, the total microcystins (MCs) production reached $2.67 \mathrm{pg} / \mathrm{cell}$. Based on liquid chromatograph-quadrupole time-of-flight mass spectrometry, three new MCs variants were proposed. This study is the first report of both decarbamoylsaxitoxin (dcSTX) and new MCs congeners synthesized by Microcystis.
\end{abstract}

Keywords: Songkhla Lake Basin; Microcystis; extracellular polymeric substances; microcystins; saxitoxin

Key Contribution: This study is the first report of both decarbamoylsaxitoxin (dcSTX) and new MCs congeners synthesized by Microcystis.

\section{Introduction}

The overgrowth of cyanobacteria leads to critical environmental problems and ecological events, including hypoxia, reducing water clarity, and imbalance of food webs. Among bloom-forming cyanobacteria, Microcystis sp. are the most abundantly reported [1]. The organisms are capable of producing several toxins, including hepatotoxic microcystins (MCs) [2] and neurotoxins (anatoxin-a, cyanopeptolin, and $\beta-\mathrm{N}$-methylamino-L-alanine) [3]. MCs cause liver failure in humans and animals and increase the risks of primary liver cancer in humans [4]. Co-production of MCs and other toxins has been reported in certain Microcystis spp. Microcystis producing both MCs and saxitoxins (STXs) were isolated from a Brazilian reservoir [5] and freshwaters in Scotland and Brazil [6]. Saxitoxins, comprising 
57 compounds, are a potent neurotoxin blocking ionic sodium and calcium channels, resulting in rapid paralysis and respiratory failure [7]. The passing of either MCs and/or STXs through the aquatic food web leads to animal deaths and human poisonings [8,9]. The World Health Organization (WHO) and the United States Environmental Protection Agency (EPA) have set guidelines to minimize $\mathrm{MCs}^{\prime}$ hazards $[10,11]$. The drinking water guidelines are $0.3 \mu \mathrm{g} / \mathrm{L}$ (bottle-fed infants and pre-school children) and $1.6 \mu \mathrm{g} / \mathrm{L}$ (school-age children and adults) MCs. The cyanobacterial guidelines for recreational water have been set as low effect $(<20,000$ cells $/ \mathrm{mL})$, moderate effect $(20,000-100,000$ cells $/ \mathrm{mL})$, and high effect $(100,000-10,000,000$ cells $/ \mathrm{mL})$. An official guideline for STXs has been established in two states in the U.S. ( $0.2 \mu \mathrm{g} / \mathrm{L}$ in Ohio and $0.3 \mu \mathrm{g} / \mathrm{L}$ in Oregon), and there is an Australia drinking water guideline $(3 \mathrm{mg} / \mathrm{L})$.

The success of a Microcystis bloom is attributed to its ability to migrate rapidly and defend against predation via colony formation and aggregation [12]. Extracellular polysaccharide (EPS) plays a critical role in colony formation. EPS also facilitates aggregated cyanobacteria floating near the water surface, known as scum formation [13]. The EPS composition and structure contribute to its matrix stability [14]. Its constituents (polysaccharide, protein, lipids, and nucleic acid) are diverse among Microcystis species [15].

Microcystis blooms have predominantly occurred in freshwater when the temperature rises [16]. Microcystis-harboring salt-tolerant genes has been reported in estuaries and marine environments $[2,17,18]$. The accumulation and biomass are facilitated by carbon fixation, availability of macronutrient nitrogen $(\mathrm{N})$ and phosphorus $(\mathrm{P})$, and physical parameters [19]. Increasing N supply would promote Microcystis sp. population [20,21] and increased MCs production [22].

Songkhla Lake Basin (SLB), a total area of $986.8 \mathrm{~km}^{2}$, is the largest natural lake in Thailand and Southeast Asia. The SLB is a unique ecosystem, which combines freshwater, brackish water, and saline water. The impurity in SLB originated from urbanization, industrialization, and artisanal fishing since along the shore are urban settlements, fishing villages, shrimp ponds, seasonally flooded forests, and rice paddy fields. Biological studies of the SLB have concentrated primarily on the taxonomy and biology of a few economically important species [23-25]. The presence of chlorophyll a (Chl-a) content has been suggested as a reason for phytoplankton propagation, including cyanobacteria in water bodies [26]. Algal blooms have occurred in SLB periodically, especially after rainy seasons [27]. The Marine and Coastal Resources Research Center, Lower Gulf of Thailand, revealed Chroococcus, Merismopedia, Microcystis, Oscillatoria, and Spirulina in SLB without algal blooming. While nutrient loading into SLB tends to increase dramatically, studies of harmful cyanobloom conditions in the lake have been limited by a lack of contaminated cyanotoxin and toxic Microcystis reports.

Our study provides proper identification of taxa and an evaluation of cyanotoxin accumulation in SLB for setting sound management procedures to reduce/prevent the exposure risk. Here, we aimed to investigate water parameters and toxin-producing Microcystis in several locations around the SLB. The toxin production and release were also determined as aquatic animal and human health benefits. This study aimed to indicate the potential harmful cyanobacteria in this unique environment and contribute to the discovery of novel toxic compounds.

\section{Results}

\subsection{General Water Quality Parameters and Bacterial Isolation}

A total of five water samples were obtained and used in this study. Four water samples were collected along accessible shores of Songkhla Lake Basin (SLB) (Figure 1). The sample sites are located close to urban settlements. One wastewater sample was collected from Hat Yai municipal wastewater treatment plant (HMWTP), which was effluent water drained to SLB (Figure 1). All samples were collected in January, the end of the rainy season (September-December). Nutrients easily load and accumulate in the lake, favoring cyanobacterial proliferation [28]. For all samples, biochemical oxygen de- 
mand (BOD) and chemical oxygen demand (COD) were 1.58-5.4 mg/L and 28-50 mg/L, respectively (Table 1). Total phosphorous and total nitrogen were $0.08-0.24 \mathrm{mg} / \mathrm{L}$ and $0.58-1.15 \mathrm{mg} / \mathrm{L}$, respectively. Other water quality characteristics included dissolved oxygen $(\mathrm{DO})$ of $1.82-7.02 \mathrm{mg} / \mathrm{L}, \mathrm{pH}$ of $6.7-8.34$, and salinity of $0.1-0.3 \mathrm{~g} / \mathrm{L}$. The lowest DO level $(1.82 \mathrm{mg} / \mathrm{L})$ that appeared at SG might have resulted from restricted water exchange, wind calm, and high tidewater. Salinity $(0.3 \mathrm{~g} / \mathrm{L})$ indicated that two water samples from Songkhla Lake, Songkhla, were brackish. The onsite temperature of the samples ranged from 29 to $32{ }^{\circ} \mathrm{C}$.

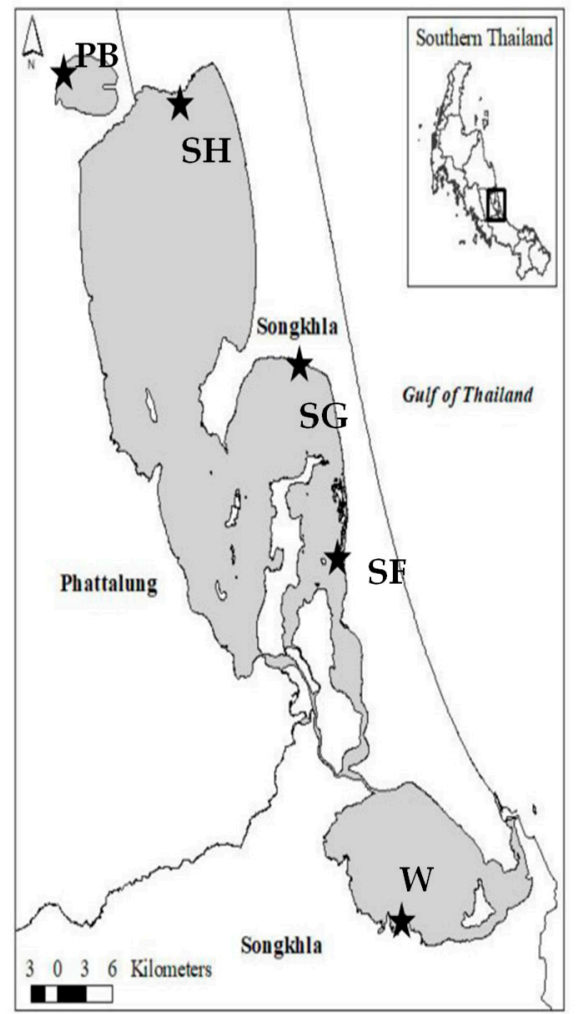

Figure 1. Map of Songkhla Lake. The map shows the locations of water sampling. PB = Thale Noi, Pattalung, Thailand; SF, SG, and SH = Songkhla Lake, Songkhla; W = Hat Yai municipal wastewater treatment plant.

Table 1. Water quality results.

\begin{tabular}{|c|c|c|c|c|c|}
\hline \multirow{2}{*}{$\begin{array}{c}\begin{array}{c}\text { Water } \\
\text { Characteristics }\end{array} \\
\text { BOD }(\mathrm{mg} / \mathrm{L})\end{array}$} & \multicolumn{3}{|c|}{ Songkhla Lake, Songkhla, Thailand } & \multirow{2}{*}{$\begin{array}{c}\text { Thale Noi, Pattalung, } \\
\text { Thailand } \\
3.63\end{array}$} & \multirow{2}{*}{$\begin{array}{c}\begin{array}{c}\text { Hat Yai Municipal } \\
\text { Wastewater Treatment } \\
\text { Plant (HMWTP) }\end{array} \\
5.4\end{array}$} \\
\hline & 4.62 & 4.62 & Below LOD * & & \\
\hline COD (mg/L) & 46 & 50 & 28 & 35 & 37.6 \\
\hline $\mathrm{TP}(\mathrm{mg} / \mathrm{L})$ & 0.11 & 0.32 & 0.08 & 0.11 & 0.24 \\
\hline TKN (mg/L) & 1.15 & 1.1 & 0.78 & 0.69 & 0.58 \\
\hline $\mathrm{DO}(\mathrm{mg} / \mathrm{L})$ & 4.37 & 1.82 & 4.58 & 7.02 & 5.8 \\
\hline Temperature $\left({ }^{\circ} \mathrm{C}\right)$ & 32 & 32 & 31 & 29 & 30 \\
\hline $\mathrm{pH}$ & 8.34 & 8.1 & 7.23 & 7.38 & 6.7 \\
\hline Salinity (g/L) & 0.3 & 0.3 & 0.1 & 0.1 & 0.1 \\
\hline Coordinates & $\begin{array}{c}7^{\circ} 47^{\prime} 335.9^{\prime \prime} \mathrm{N} \\
100^{\circ} 15^{\prime} 28.0^{\prime \prime} \mathrm{E}\end{array}$ & $\begin{array}{c}7^{\circ} 4610.0^{\prime \prime} \mathrm{N} \\
100^{\circ} 18^{\prime} 08.8^{\prime \prime} \mathrm{E}\end{array}$ & $\begin{array}{c}7^{\circ} 41^{\prime} 11.0^{\prime \prime} \mathrm{N} \\
100^{\circ} 12^{\prime} 31.1^{\prime \prime} \mathrm{E}\end{array}$ & $\begin{array}{c}7^{\circ} 46^{\prime} 40.6^{\prime \prime} \mathrm{N} \\
100^{\circ} 07^{\prime} 22.1^{\prime \prime} \mathrm{E}\end{array}$ & $\begin{array}{c}7^{\circ} 46^{\prime} 40.6^{\prime \prime} \mathrm{N} \\
100^{\circ} 07^{\prime} 22.1^{\prime \prime} \mathrm{E}\end{array}$ \\
\hline Isolates & SF11 & $\begin{array}{l}\text { SG03, SG10, } \\
\text { SG11, SG12 }\end{array}$ & SH12, SH13 & PB07 & WOT01, WIN01 \\
\hline
\end{tabular}

* $1.56 \mathrm{mg} / \mathrm{L}$ biochemical oxygen demand (BOD), chemical oxygen demand (COD), total phosphorus (TP), total Kjeldahl nitrogen (TKN), and dissolved oxygen (DO). 
Cyanobacteria were isolated from the water samples. Ten green colonies were selected and observed under an optical microscope. The cells ranged from 1 to $5 \mu \mathrm{m}$ in diameter with a round shape and green color. The $16 \mathrm{~S}$ rDNA analysis indicated that all strains fell into Microcystaceae family and Microcystis genus. The phylogeny based on $16 \mathrm{~S}$ rDNA sequences was generated by the neighbor-joining tree method; compared with M. aeruginosa, M. panniformis, $M$. ichthyoblabe, $M$. wesenbergii, $M$. viridis, and Gloeothece membranacea; and deposited in the NCBI database (Figure 2). Most Microcystis isolates were closely related to $M$. aeruginosa strains NIES-843 (NR_074314.1), except WIN01. SG12, SG03, and SG11 isolated from the exact location were in the same phylogenic group. SH13, SH12, and SF11 also showed similar 16S rDNA gene sequences. Three Microcystis strains isolated from Songkhla Lake (SG10), Thale Noi (PB07), and HMWTP (WOT01) fell into the same cluster. Our results reveal that despite the absence of cyanobacterial bloom, Microcystis was detected. Cyanoblooom is facilitated by other environmental factors, including nutrients, carbon dioxide, weather conditions, water bodies, salinity, heavy metals, and sunlight $[29,30]$.

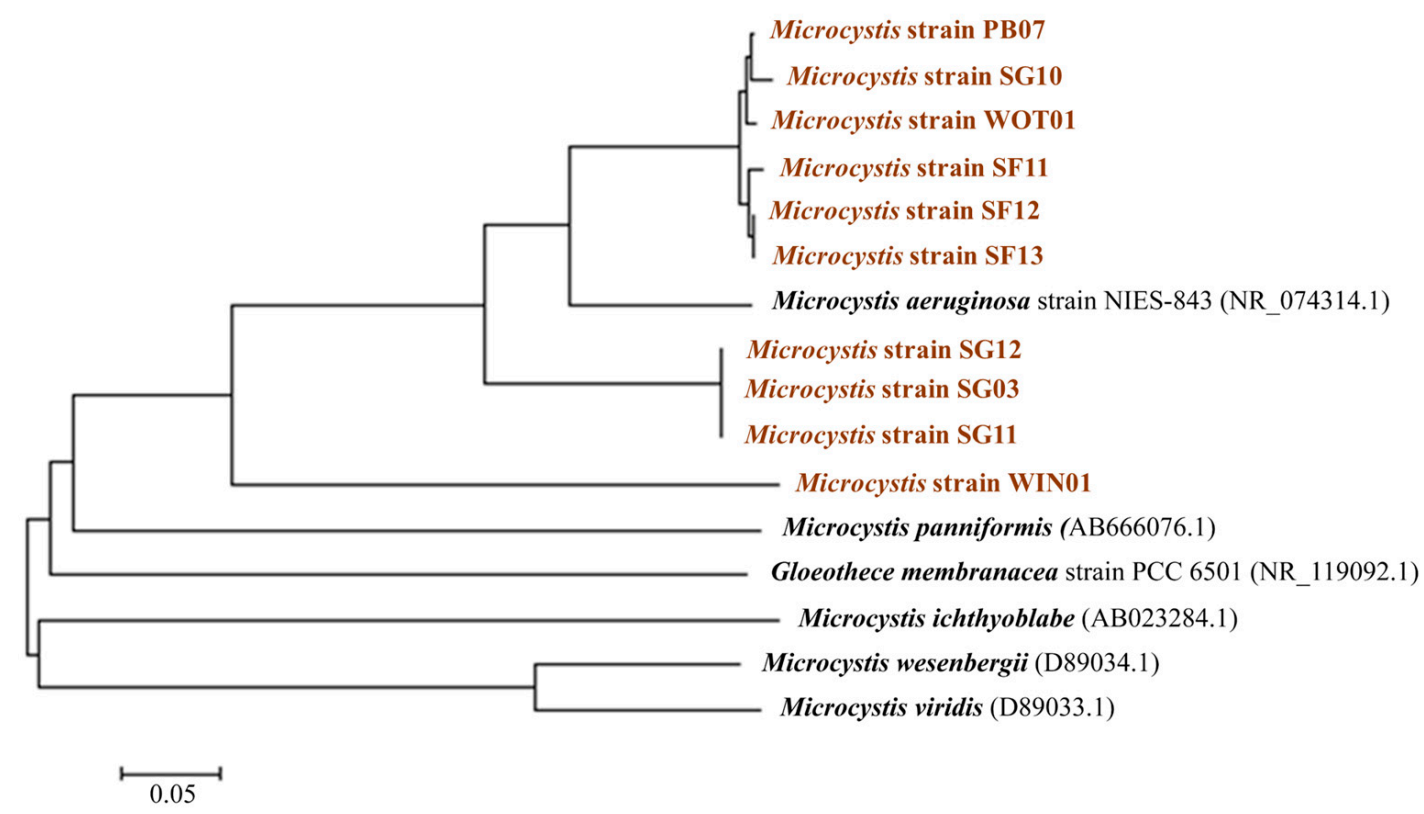

Figure 2. Phylogenetic tree based on $16 \mathrm{~S}$ rDNA gene sequences. The bar scale indicates $5 \%$ divergence.

\subsection{Microcystin Genes and a Saxitoxin Gene Analysis}

Microcystin genes and a saxitoxin gene were investigated in all 10 strains. The MC gene cluster is arranged in two divergently transcribed operons (ORFs), mcy A-C and mcy D-J. The $m c y$ A-C operon is engaged in synthesizing amino acids attached to Adda through a subsequent modification or tailoring by $m c y J, m c y E$, and $m c y F$ genes [31]. The $m c y A$ genes are widely employed to detect the toxigenic Microcystis genus [32-34]. Our results show that all isolates carried $m c y A$ (Table 2). The $m c y A^{a}$ primers detected the target gene in 5 out of 10 strains, while the $m c y A$ gene was detected in 9 of 10 strains by $m c y A^{b}$ primers. The $m c y A^{b}$ primers were created based on nucleotides of toxigenic Microcystis and Planktothrix strains [35]. However, certain non-toxic strains harbor the mcy genes [36,37]. Our study suggests that the mcyA primers might be restricted by a small nucleotide database of the toxic strains and that $m c y A$ sequences are divergent among Microcystis isolates [32]. A report on MCs detection in Greece revealed that despite the presence of the toxin, the $m c y A$ gene was not detected in freshwater samples [38]. Therefore, MCs prediction strictly based on molecular assay might be insufficient. Combining molecular techniques (PCR) and other techniques such as chemical methods (HPLC) and immunoassay will assure the MC presence. 
Table 2. Genotypic and phenotypic characteristics of Microcystis spp.

\begin{tabular}{|c|c|c|c|c|c|c|}
\hline \multirow[b]{2}{*}{ Microcystis Sp. } & \multicolumn{3}{|c|}{ Genotypes } & \multicolumn{3}{|c|}{ Phenotypes } \\
\hline & $m c y A^{a}$ & $m c y A^{b}$ & $s t x t A$ & $\begin{array}{l}\text { The Specific Growth } \\
\text { Rate }^{*}, \mu\left(\text { Day }^{-1}\right)\end{array}$ & $\begin{array}{l}\text { Chlorophyll a } \\
\text { (Day } 15, \mu \mathrm{g} / \mathrm{mL})\end{array}$ & $\begin{array}{l}\text { MCs Production } \\
\text { (Day } 15, \mu \mathrm{g} / \mathrm{mL} \text { ) }\end{array}$ \\
\hline SF11 & - & + & - & 0.291 & 3.386 & 194 \\
\hline SG03 & + & + & + & 0.312 & 4.139 & 314 \\
\hline PB07 & - & + & - & 0.332 & 3.514 & 188 \\
\hline SG10 & + & + & - & 0.312 & 4.182 & 210 \\
\hline SG11 & + & - & + & 0.312 & 4.024 & 306 \\
\hline SG12 & + & + & + & 0.329 & 4.37 & 281 \\
\hline SH12 & + & + & - & 0.211 & 3.889 & 43 \\
\hline SH13 & - & + & - & 0.209 & 4.173 & 142 \\
\hline WOT01 & - & + & + & 0.271 & 3.982 & 279 \\
\hline WIN01 & - & + & + & 0.261 & 4 & 273 \\
\hline
\end{tabular}

* The specific growth rate was calculated based on cell number.

Our results show that 5 of 10 strains were positive for $s x t A$ and also carried $m c y A$ (Table 2). The STXs biosynthesis initiates via PKSs-like enzymes encoded by sxt $A$ [39]. The $s x t A$ is a core gene among the gene clusters for the synthesis of STX and analogs $[40,41]$. This gene has been widely used to detect STX producers [42].

\subsection{Growth and EPS Composition}

The Microcystis density and Chl- $a$ content were measured. The specific growth rate of all isolates was $0.2-0.3 \mathrm{day}^{-1}$, as shown in Table 2. As a general metric for algal biomass, Chl- $a$ was employed as a reference for cyanoblooms [43]. Our results show that Chl- $a$ production was consistent with bacterial growth. Chl- $a$ was 0.1 to $4 \mu \mathrm{g} / \mathrm{mL}$ from day 0 to day 15.

Extracellular polymeric substance (EPS) of Microcystis is produced as part of the metabolism process. It forms and surrounds the cell surface as a protective barrier between the cell and the external environment [12,44,45]. The content, types, and composition of EPS also facilitate colony formation, impacting the distribution and persistence of cyanobacteria [46-48]. A study by Holland et al. suggested that Microcystis with increased colony size contained higher MCs [49]. Therefore, correlations between MCs and the content and composition of EPS are needed to be revealed.

Here, we determined EPS content and composition in 10 Microcystis isolates (Figure 3). The total EPS varied from 0.37 to $0.49 \mu \mathrm{g} / \mathrm{mL}$. The highest total EPS concentration was found in SG10. For all isolates, the average soluble EPS (sEPS) concentration (Figure 3b) was roughly twice higher than the average bound EPS (bEPS) concentration (Figure 3a) ( 0.27 vs. $0.14 \mu \mathrm{g} / \mathrm{mL}$ ). Our results confirm the finding by Xiao et al. (2018), that Microcystis are commonly unicellular cells under an axenic condition [12]. High sEPS content was found in unicellular cells, while increasing bEPS content could be concluded for colony formation [46]. The proportion between protein and carbohydrate in sEPS in 10 isolates was similar. In contrast, the protein proportion in bEPS was higher, ranging from 2.014 to 3.056 at an average value of 2.369 , which was in agreement with a previous study [50]. However, the proportions of bEPS in this study were inconsistent with Xu et al. (2013), which revealed a higher polysaccharides content than protein. The EPS composition also depends on cyanobacterial species, including Synechocystis sp. (FACHB898), Synechococcus 7942 (FACHB805), Microcystis flosaquae (FACHB1028), Scytonema hofmanni (FACHB 248), and Nostoc sp. (FACHB106) [51].

During cyanobloom, large aggregated colonies form scum floating on a water body's surface [52]. This upward cell migration is enhanced by photosynthetic activity resulting in $\mathrm{O}_{2}$ saturation and nucleation into bubbles [13,53] and gas vesicles in Microcystis cells [47]. The $\mathrm{O}_{2}$ bubble is trapped inside EPS, indicating that scum formation is highly correlated with the amount of EPS production $[13,54]$. Here, the scum formation was enhanced 
by culturing in high concentration media and was found in SG03, SG11, and SH13 after culturing for 2 to 7 days, in agreement with previous studies [13,53]. The remaining isolates did not generate scums over the incubation period. Future work should be conducted to determine the effects of EPSs composition on scum formation and large aggregated colonies.

(a)

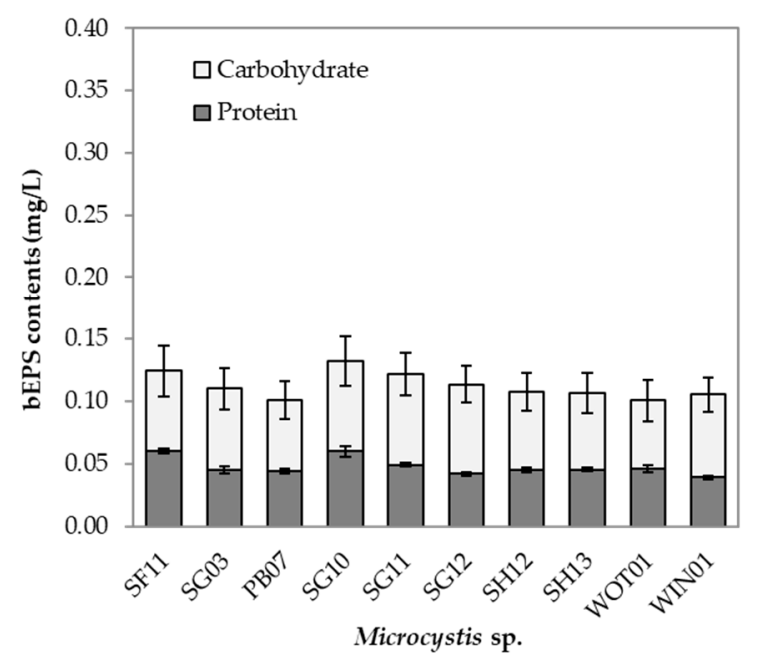

(b)

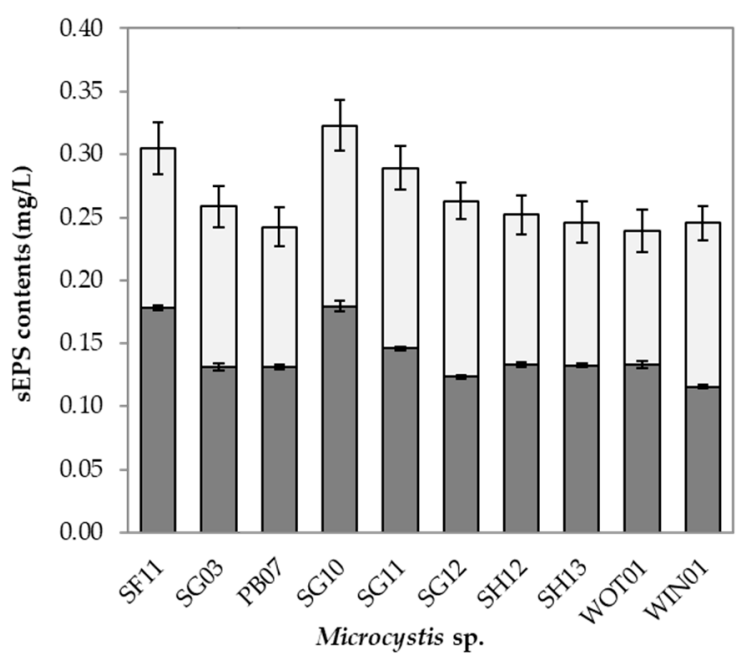

Figure 3. Protein and carbohydrate content of bEPS (a) and sEPS (b) after 15 days of incubation. The data show the means \pm standard deviations based on triplicated experiments.

\subsection{Microcystins Production of Microcystis Sp.}

After 15 days of culturing intracellular microcystins (IMCs) and extracellular microcystins (EMCs), production in all Microcystis isolates was determined by ELISA. This technique is recommended to quantify several MCs variants in cyanobacterial cells and to track MCs production in water bodies $[55,56]$. The test kit is designed to detect Adda, which is a non-protein amino acid at position 5 in MCs, with cross-reactivity between different MCs variants [57]. Our results show that high IMCs production ranging from 210 to $314 \mu \mathrm{g} / \mathrm{mL}$ was observed in Microcystis isolated from Songkhla Lake. Microcystis sp. isolated from HMWTP was approximately $280 \mu \mathrm{g} / \mathrm{mL}$ of MCs (Table 2). The EMCs were not detected in any isolates. The absence of EMCs might be the result of low cell density after 15 days of culturing $\left(10^{7} \mathrm{CFU} / \mathrm{mL}\right)$ and the kit's sensitivity. More prolonged cultivation than 15 days resulted in EMCs production (Figure 4b). SG03 produced IMCs at the highest concentration of $1.3 \mathrm{pg} /$ cell, while SH13 was the lowest in IMCs production at $0.14 \mathrm{pg} /$ cell. Microcystis SG03 was observed under SEM. As seen in Figure 4a, with round shape, cell diameter ranged from 3 to $5 \mu \mathrm{m}$.

\subsection{Kinetics of MCs Production Based on Microcystis Growth}

Growth and MCs kinetics of SG03 were investigated from day 0 to day 30 (Figure $4 \mathrm{~b}$ ). The initial IMCs content at $0.03 \mathrm{pg} /$ cell on day 0 was detected in the inoculum $\left(6 \times 10^{6} \mathrm{CFU} / \mathrm{mL}\right)$. On day 5 , the specific growth rate $(\mu)$ based on cell number was 0.522 day $^{-1}$, indicating that the exponential growth phase followed the late exponential growth phase from day 5 to $15\left(\mu=0.186\right.$ day $\left.^{-1}\right)$. The stationary growth phase spanned from day 20 to day 30 $\left(\mu=0.002\right.$ day $\left.^{-1}\right)$. MCs production was determined along the growth curve. The IMCs were dramatically produced at $1.94 \mathrm{pg} /$ cell during the exponential growth phase (day 10), and then the production was steady when cyanobacteria entered the stationary growth phase (Figure $4 \mathrm{~b})$. The EMC production $(0.06 \mathrm{pg} / \mathrm{cell})$ was measured in the late exponential growth phase and dramatically rose on day $20(0.66 \mathrm{pg} / \mathrm{cell})$ during stationary growth, indicating cell death. Our results suggest that the MCs were the primary metabolite produced intracellularly at the log phase. Our finding is well supported by previous work 
in which the maximum MCs production of Microcystis was found in the log phase and persisted for months $[43,58,59]$. Studies have shown that MCs production rescues the cells from damage by photosynthesis, reactive oxygen species [60], and imbalance of C:N by redirecting primary metabolism in cells [61].

(a)

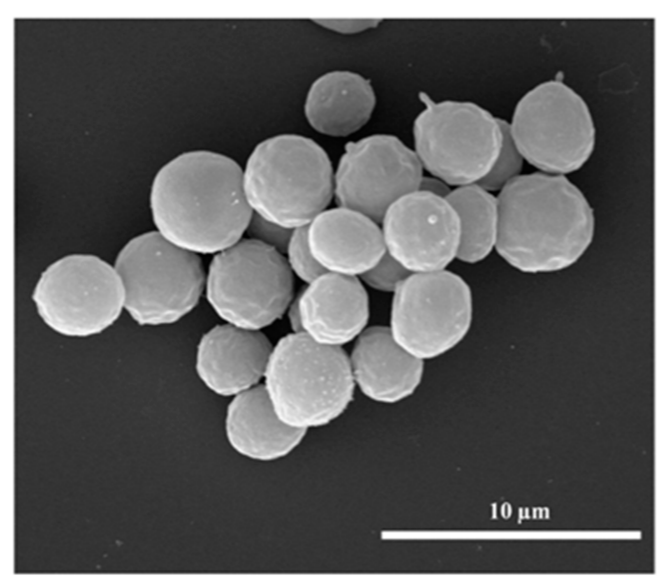

(b)

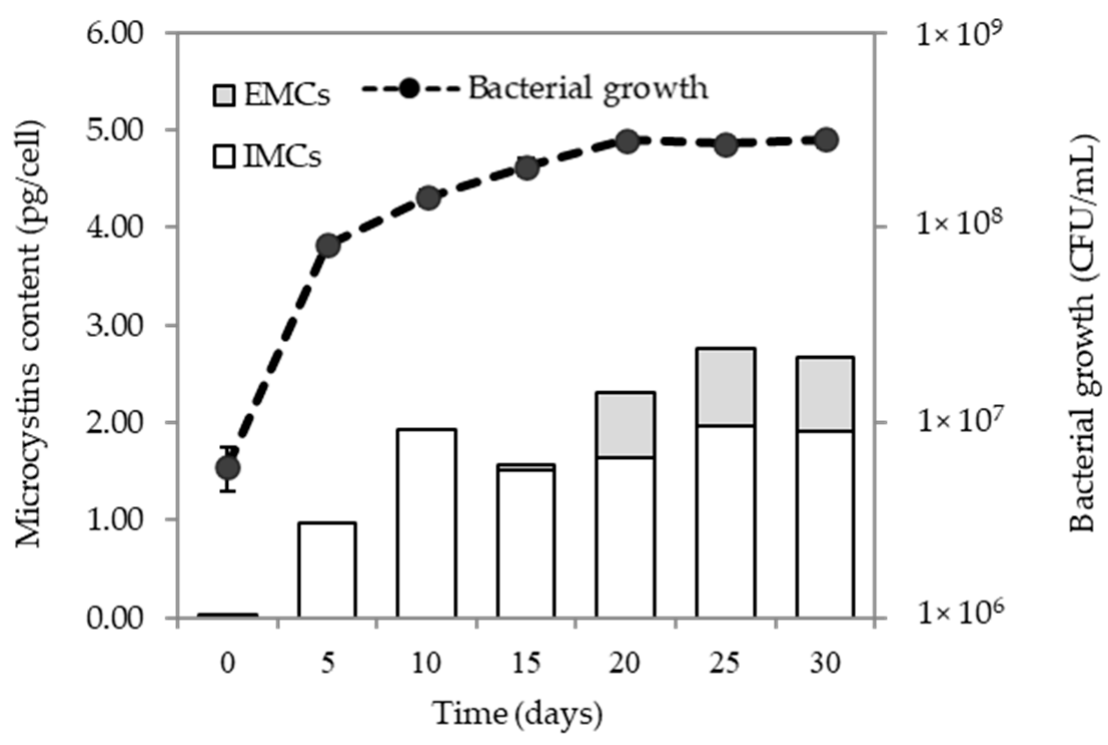

Figure 4. A 30-day axenic culture of Microcystis SG03; (a) SEM image of Microcystis cells at 10 days and (b) MCs production and growth of SG03.

\subsection{Identification of Cyanotoxins}

The cyanotoxin profiles of SG03 were investigated by LC-QTOF MS. Here, the emergence of both MCs and decarbamoylsaxitoxin (dcSTX)-producing Microcystis SG03 is reported (Table 3). At $14.579 \mathrm{~min}$ of the retention time, compound 1 was detected with $\mathrm{m} / \mathrm{z} 257.1357, \Delta-0.63 \mathrm{ppm}$. This compound was annotated as dcSTX with a score of $85 \%$ (Table 3; Figure 5a). The other three compounds were previously unreported MCs based on their probable chemical composition/structure and mass properties [62]. As shown in Figure 5b, they were: $\mathrm{C}_{57} \mathrm{H}_{77} \mathrm{~N}_{7} \mathrm{O}_{16}\left([\mathrm{M}+2 \mathrm{H}]^{2+}\right.$ mass $\left.1115.5409, \Delta 1.56 \mathrm{ppm}\right)$; $\mathrm{C}_{52} \mathrm{H}_{71} \mathrm{~N}_{7} \mathrm{O}_{15}\left([\mathrm{M}+2 \mathrm{H}]^{2+}\right.$ mass 1033.5005, $\left.\Delta 0.29 \mathrm{ppm}\right)$; and $\mathrm{C}_{49} \mathrm{H}_{71} \mathrm{~N}_{7} \mathrm{O}_{13}\left([\mathrm{M}+2 \mathrm{H}]^{2+}\right.$ mass $965.5125, \Delta-1.17 \mathrm{ppm}$ ); designated as compounds 2,3 , and 4 , respectively. The mass accuracy tolerances $(\Delta<5 \mathrm{ppm})$ between found mass and calculated mass of compounds 2 , 3 , and 4 were $\Delta 1.61 \mathrm{ppm}, \Delta 0.29 \mathrm{ppm}$, and $\Delta-1.55 \mathrm{ppm}$, respectively. 
Table 3. Identification of cyanotoxin detected by LC-QTOF MS analysis in Microcystis strains SG03 isolated from SLB, their retention times (Rt), observed $m / z$ values, and mass accuracy tolerances (Diff, ppm).

\begin{tabular}{|c|c|c|c|c|c|c|c|}
\hline & Compound Name & $\begin{array}{l}\text { Neutral } \\
\text { Formular }\end{array}$ & Confidence & Rt (min) & $m / z$ & Mass & $\begin{array}{r}\text { Diff. } \\
\text { (ppm) }\end{array}$ \\
\hline 1 & Decarbamoylsaxitoxin & $\mathrm{C}_{9} \mathrm{H}_{16} \mathrm{~N}_{6} \mathrm{O}_{3}$ & Confirmed & 6.431 & 257.136 & 256.1286 & -0.63 \\
\hline 2 & {$\left[\mathrm{Gly}^{1}, \mathrm{D}-\mathrm{Asp}^{3},(\mathrm{EtOH}) \mathrm{Mdhb}^{7}\right] \mathrm{MC}-\mathrm{Y}(\mathrm{H} 2) \mathrm{Y}(\mathrm{OMe})$} & $\mathrm{C}_{57} \mathrm{H}_{77} \mathrm{~N}_{7} \mathrm{O}_{16}$ & Tentative & 4.132 & 558.778 & 1115.5409 & 1.56 \\
\hline 3 & {$\left[\mathrm{~L}-\mathrm{Ser}^{1}, \mathrm{D}-\mathrm{Asp}{ }^{3}\right] \mathrm{MC}-\mathrm{LY}(\mathrm{OMe})$} & $\mathrm{C}_{52} \mathrm{H}_{71} \mathrm{~N}_{7} \mathrm{O}_{15}$ & Tentative & 4.926 & 517.7576 & 1033.5005 & 0.29 \\
\hline 4 & {$\left[\mathrm{DMAdda}^{5}, \mathrm{Mglu}^{6}, \mathrm{Mala}^{7}\right] \mathrm{MC}-\mathrm{Y}(\mathrm{H} 4) \mathrm{A}$} & $\mathrm{C}_{49} \mathrm{H}_{71} \mathrm{~N}_{7} \mathrm{O}_{13}$ & Tentative & 4.929 & 483.764 & 965.5125 & -1.17 \\
\hline
\end{tabular}

(a)

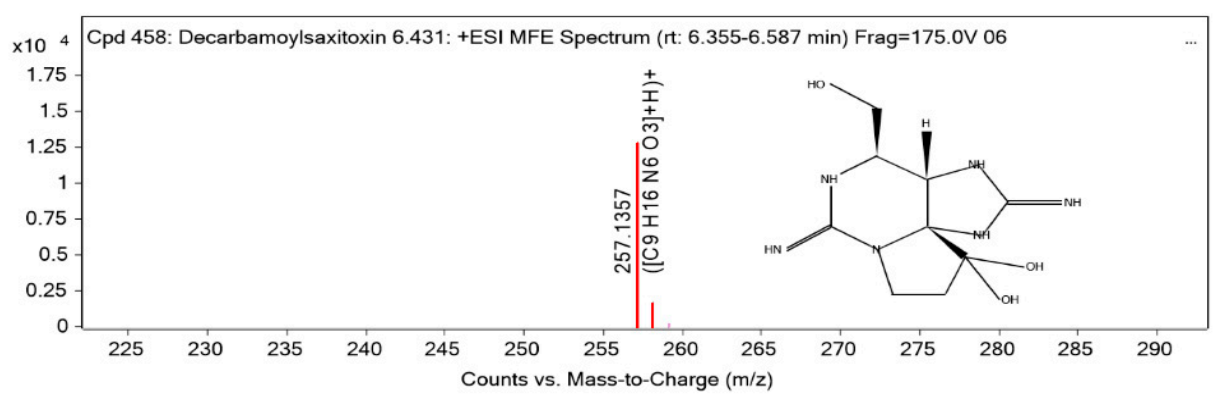

(b)

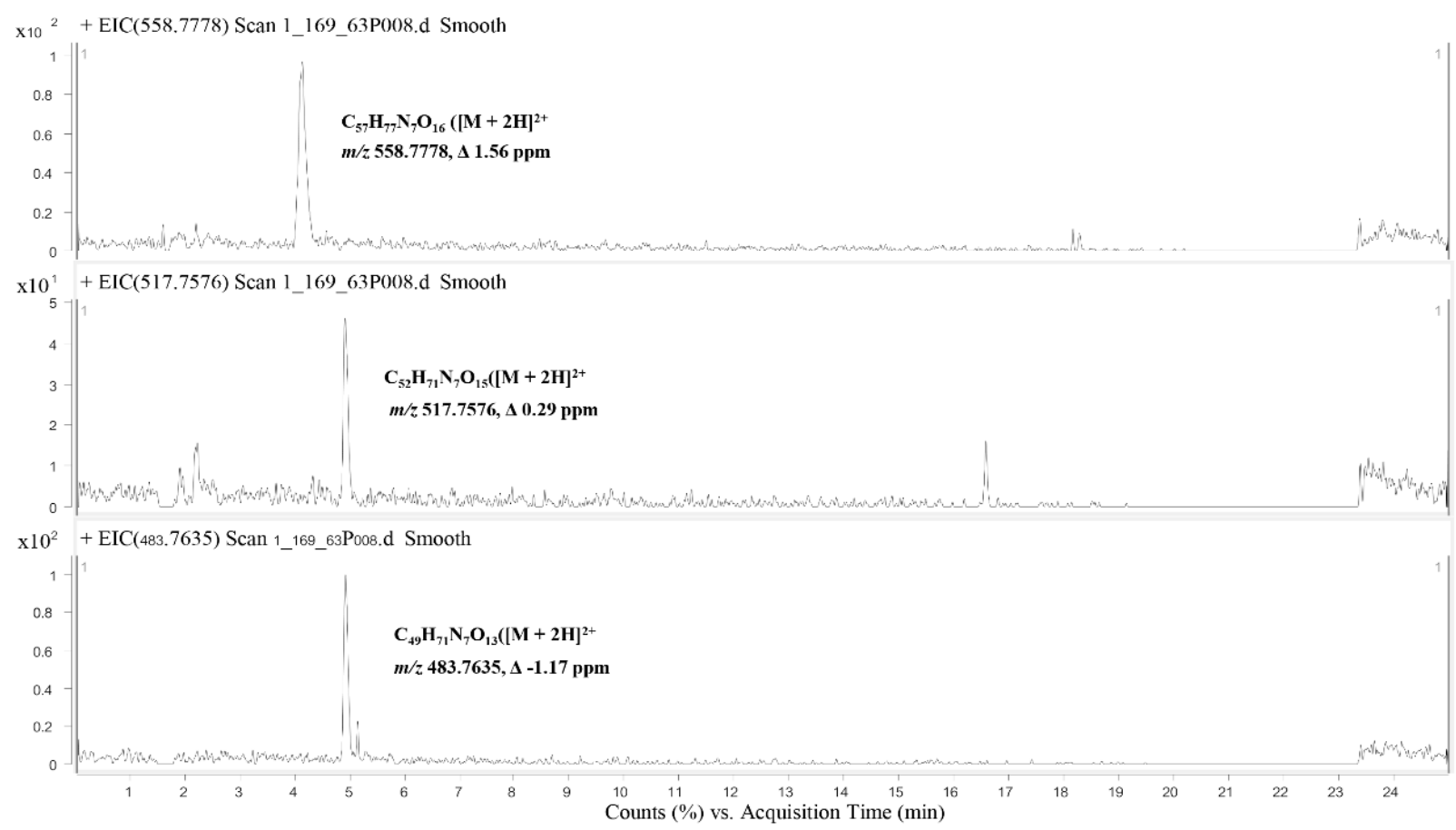

Figure 5. LC-QTOF MS spectrum (a) decarbamoylsaxitoxin, (b) tentative microcystins.

\section{Discussion}

Microcystis blooms cause ecosystem loss as well as threats to public health and animals. Microcystis possesses a well-known hepatotoxin, MCs; a few strains also produce neurotoxin ( $\beta-\mathrm{N}$-methylamino L-alanine and paralytic shellfish poison) [63]. However, no STX biosynthesis genes have been identified in Microcystis. 
Various factors facilitate the abundance of cyanobacteria in aquatic environments. EPSs prolong cyanobacterial persistence in water and protect cells from the environment. Cyanobacterial aggregation and scum formation can be promoted by higher EPS content $[13,47,64]$. The EPS composition involves colony size and colony formation $[12,65]$. Microcystis with increased colony size was reported to produce higher MCs [49]. Our results show that the average sEPS concentration was higher than the average bEPS concentration as a unicellular cell under an axenic condition. There was no statistical difference between EPS content and composition among all isolates. Therefore, correlations between MCs and EPS content and composition cannot be defined in this study. Associations of MCs and EPS types, content, and composition still need to be discovered.

The MCs can contaminate different environmental compartments, including sediment, animals, and aquatic and terrestrial plants [66]. MCs produced by Microcystis could persist for months in axenic cultures [67]. In our study, IMC production of Microcystis SG03 remained constant after 20 days of incubation. The averaged MCs production was $1.91 \mathrm{pg} /$ cell on day 30 of culturing, with stable cell density. Under low nutrient/starvation conditions with sufficient light, the SG03 cells entered the stationary phase without changing MCs production. However, other studies reported increasing MCs production under nutrient starvation [68,69]. During stress conditions, MCs synthesis is enhanced by phycobilisomes degradation and by the toxins combined with phycobilins, stabilizing cell integrity $[68,70]$. Furthermore, MCs might protect the cells from oxidative stress under insufficient nutrients [71]. Our study indicates that Microcystis can produce MCs and survive for a long time, suggesting a need for a vigilant surveillance program on toxigenic Microcystis and MCs in aquatic areas.

To date, at least $279 \mathrm{MC}$ s have been reported with various formulas: $\mathrm{C}_{44-47} \mathrm{H}_{63-84}$ $\mathrm{N}_{7-13} \mathrm{O}_{12-17}$ [72,73]. MCs structures are composed of cyclic oligopeptides consisting of seven amino acids, including D-Ala ${ }^{1}-X^{2}-\mathrm{D}-\mathrm{MeAsp}{ }^{3}-Z^{4}-\mathrm{Adda}^{5}-\mathrm{D}-\mathrm{Glu}^{6}-\mathrm{Mdha}^{7}$ [31]. The $X$ and $Z$ are variable $L$ amino acids. Adda is a 3-amino-9-methoxy-2, 6,8-trimethyl10-phenyl-deca-4,6-dienoic acid, and Mdha is N-methyldehydroalanine. In our study, two compounds (2 and 3) showed characteristics of MCs containing Adda at position 5, while compound 4 consisted of DMAdda (Table 3 and Figure 5). D-Ala is mostly found in position 1 [72], consistent with compound 4. Position 1 of compounds 2 and 3 contained Gly and L-Ser, which have been found in MCs produced by Nostoc sp. and cyanobacterial mat samples [74,75]. In position 3 of MCs, D-erythro- $\beta$-methyl isoaspartic acid (D-MeAsp) and D-erythro-isoaspartic acid (D-Asp) are conserved with approximately $56 \%$ and $44 \%$, respectively [72]. Our study shows that D-Asp was presented in compounds 2 and 3. Another highly conserved amino acid is D-Glu at position 6 [31]. The D-Glu could become Glu(OMe) from an extraction step through methanolic solutions [76-78]. Here, Glu(OMe) was found in compounds 2 and 4. The amino acid residue in position 7 is variable with commonly found $\mathrm{N}$-methyldehydroalanine (Mdha). The Mdhb existed in compound 2, while compound 4 possessed tentative Mala. Even though several MC congeners have been presented in the environment and laboratories, their toxicity has been inadequately assessed.

Dominant STXs producers are filamentous cyanobacteria, including Anabaena, Aphanizomenon, Cylindrospermopsis, Lyngbya, Phormidium, Planktothrix, Raphidiopsis, Scytonema, and Woronichinia [79-85]. Only three unicellular Microcystis isolates were reported to produce STXs [5,6]. One of them co-produced mono-sulfated STX (GTX 1-4) and [L-ser $\left.{ }^{7}\right]$ MC-RR [5]. The other two isolates from eutrophic lakes (Arresø, Bagsværd Sø and Lyngby Sø) and mesotrophic lakes (Furesø and Esrum Sø) in Denmark produced STX without MCs production information [6]. Our study is the second to report the co-production of MCs and STX (by SG03). However, we, for the first time, discovered that Microcystis also synthesized dcSTX. Currently, 57 natural STX analogs have been identified [41]. The toxin divergence depends on PST-transforming enzymes between toxigenic organisms and contaminated bivalves [86]. Carbamoyl groups of the STXs are decarbamoylated, resulting in the presence 
of dcSTX. The enzymatic decarbamoylation of STX was a major presence in mussels and human metabolically active tissues $[86,87]$.

The SLB has a unique ecosystem as fresh, brackish, and saline water lead to plenty of bioresources and high biodiversity. This area has benefited aquaculture, agriculture, factories, tourist resorts, and housing developments. Here, we isolated toxigenic Microcystis, which produced both MCs and STXs, from SLB with no observed blooms. Christensen et al. (2019) reported the production of both toxins before visible blooms [88]. When season changes combine with other environmental factors, harmful cyan blooms occur. In Thailand, MC accumulation was found in prawn farms [89,90], fish ponds [90-92], and recreational reservoirs $[93,94]$, especially in the temperate region of the country with high $\mathrm{N}$ and P concentrations. In contrast, the reports of STX from Thailand were associated with only freshwater puffers $[95,96]$. The observation of MCs- and STXs-producing cyanobacteria in our study calls for more research on harmful cyanobacterial communities and toxin distribution in recreation areas and aquaculture farms in Songkhla Lake.

\section{Conclusions}

This is the first report of Microcystis in Songkhla Lake, Thailand. In axenic culture, Microcystis produced sEPS 2 times more than bEPS. The ratio of protein and carbohydrate was equal in sEPS, while the protein fraction was higher than carbohydrate in bEPS. All isolates produced MCs. One isolate (SG03) presented both MCs and dsSTX. SG03 produced three new tentative MC variants as undescribed congeners. The MCs accumulation in SG03 was observed until 30 days of incubation, and the toxin was released extracellularly on day 15. The IMCs were synthesized mainly in the middle exponential growth phase, while the EMCs were initially produced at the stationary growth phase. The rising of total MCs synthesis was observed during the exponential growth phase and was constantly produced during the stationary growth phase. This study indicates that harmful cyanobacteria could present in water bodies without visible blooms. The unique complexity of SLB provided groups of Microcystis producing novel toxic compounds. We exhibited that Microcystis extended some distance into brackish and/or marine water bodies. Further studies should focus on the effects of water quality parameters, including $\mathrm{N}$ and $\mathrm{P}$ on Microcystis aggregation, scum formation, and toxin production, thereby preventing harmful effects of cyanobacteria and their toxins.

\section{Materials and Methods}

\subsection{Water Quality Characterization}

Four lake water samples from Songkhla Lake Basin (SLB), Thailand $\left(7687 \mathrm{~km}^{2}\right.$ of land area and $1042 \mathrm{~km}^{2}$ of the Lake surface), were collected on 25 January 2019, without visible blooms (Figure 1). These locations were located close to urban settlements. Effluent water drained to the SLB was collected from the Hat Yai municipal wastewater treatment plant (HMWTP) on 25 January 2019 (Figure 1). The 5 samples containing $1 \mathrm{~L}$ with duplicates were taken at a $50 \mathrm{~cm}$ depth and kept on ice during transportation. The water quality, including biochemical oxygen demand (BOD), chemical oxygen demand (COD), total phosphorus (TP), total Kjeldahl nitrogen (TKN), temperature, $\mathrm{pH}$, and salinity was characterized. All samples were used for Microcystis isolation in further experiments.

\subsection{Microcystis Spp. Isolation}

Ten milliliters of water samples and the duplicates were enriched in $10 \mathrm{ml}$ of $2 \times \mathrm{BG}-11$ broth ( $\mathrm{pH}$ 7.5) [97]. The samples were incubated under a 12:12 h light/dark cycle ( $25 \mu \mathrm{mol}$ photon $\mathrm{m}^{-2} / \mathrm{s}$, cool fluorescent light) at $25^{\circ} \mathrm{C}$ for 14 days and hand-shaken three times a day. The enriched samples were then streaked onto BG-11 agar plates supplemented with imipenem $(10 \mu \mathrm{g} / \mathrm{mL})$ [97], followed by incubation for 7-14 days under the above conditions. The isolated green bacterial colonies were obtained, and their morphology was documented. Characteristics of the cyanobacterial cells were observed under an optical microscope. 


\subsection{Cyanobacterial DNA Extraction}

All cyanobacterial isolates were cultivated in $50 \mathrm{~mL}$ BG-11 under the above conditions for 10 days. Then, DNA from each isolate was extracted. The DNA extraction method was modified from Hisbergues et al. (2003) and Rogers and Bendich (1989). Briefly, the culture was centrifuged at $10,000 \times g$ for $5 \mathrm{~min}$, and the pellet was resuspended in $300 \mu \mathrm{L}$ suspension buffer (50 mM Tris-HCL ( $\mathrm{pH} 8), 5 \mathrm{mM}$ EDTA ( $\mathrm{pH} 8)$, and $50 \mathrm{mM} \mathrm{NaCl}$ ), followed by the addition of lysozyme $(2 \mathrm{mg} / \mathrm{L})$ and proteinase $\mathrm{K}(2 \mathrm{mg} / \mathrm{mL})$. The cell suspension was incubated at $37^{\circ} \mathrm{C}$ for $30 \mathrm{~min}$ and at $60^{\circ} \mathrm{C}$ for $10 \mathrm{~min}$. The mixture was added with an equal volume of lysis buffer ( $2 \%$ CTAB, $2 \%$ SDS, $1.4 \mathrm{M} \mathrm{NaCl}, 20 \mathrm{mM}$ EDTA (pH 8), $100 \mathrm{mM}$ Tris- $\mathrm{HCl}(\mathrm{pH} 8), 2 \%$ 2-mercaptoethanol) and incubated at $70{ }^{\circ} \mathrm{C}$ for $1 \mathrm{~h}$. The DNA was separated by adding an equal volume of phenol/chloroform/isoamyl alcohol $(25: 24: 1, v / v)$, followed by centrifugation at $10,000 \times g$ for $15 \mathrm{~min}$. The supernatant was collected and mixed with an equal volume of chloroform/isoamyl alcohol $(24: 1, v / v)$. Then, the mixture was centrifuged at $10,000 \times g$ for $15 \mathrm{~min}$. The supernatant containing DNA was precipitated with 0.3 volume of $3 \mathrm{M}$ sodium acetate and 1 volume of isopropanol and kept at $-20^{\circ} \mathrm{C}$ for $2 \mathrm{~h}$. After centrifugation at $10,000 \times g$ for $20 \mathrm{~min}$, the DNA pellet was obtained and washed with $1 \mathrm{~mL}$ of $70 \%$ ethanol. The pellet was air-dried and dissolved with $30 \mu \mathrm{L}$ sterilized deionized water and kept at $-20^{\circ} \mathrm{C}$.

\subsection{Detection of Microcystin Genes, Saxitoxin Gene and $16 S$ rDNA by PCR}

Microcystin gene $(m c y A)$, saxitoxin gene $(s t x A)$ [98], and $16 \mathrm{~S}$ rDNA were investigated by PCR. Two sets of $m c y A$ primers were applied: $m c y A^{a}$ primers [35] and $m c y A^{b}$ primers [32]. PCR amplifications were performed using a $25 \mu \mathrm{L}$ mixture of $5 \mu \mathrm{L}$ buffer $\left(\mathrm{dNTP}, \mathrm{Mg}^{2+}\right.$ ) (Bioline Reagents Ltd, London, UK), $3 \mu \mathrm{L}$ each of primer-F and primer-R $(1 \mu \mathrm{M}), 0.25 \mu \mathrm{L}$ MyTaq polymerase (1 unit), $1 \mu \mathrm{L}$ DNA template $(20 \mathrm{ng} / \mathrm{mL})$, and $12.75 \mu \mathrm{L}$ deionized water. The PCR thermal cycling programs included initial denaturation at $94{ }^{\circ} \mathrm{C}$ for $2 \mathrm{~min}$, followed by 30 cycles at $94{ }^{\circ} \mathrm{C}$ for $30 \mathrm{~s}$, annealing for $30 \mathrm{~s}$, and extension at $72{ }^{\circ} \mathrm{C}$ for $1 \mathrm{~min}$, with a final extension at $72{ }^{\circ} \mathrm{C}$ for $10 \mathrm{~min}$. The PCR products were observed by electrophoresis on $1.5 \%$ agarose gels in $0.5 \mathrm{TBE}$ buffer at $100 \mathrm{~V}$ for $40 \mathrm{~min}$, with $1 \mathrm{~kb}$ DNA Ladder (Solis BioDyne) as the molecular-sized marker. The agarose gel was stained with ethidium bromide and imaged under a benchtop UV transilluminator (LUMIstar ${ }^{\circledR}$ Omega. Ortenberg, Germany).

Cyanobacterial identification was based on $16 \mathrm{~S}$ rDNA sequencing. Briefly, the $16 \mathrm{~S}$ rDNA was amplified using the primer 27F and 809R [99]. The PCR product was purified using a GenepHlow ${ }^{\mathrm{TM}}$ Gel/PCR kit and sequenced (Novogene co. Ltd., Cambridge, UK). Sequences were aligned using ClustalW followed by comparing their similarity with the other sequences in the Genbank database. A phylogenetic tree was constructed via a neighbor-joining (NJ) method by MEGA 7.0 software with 1000 replicates of bootstrap.

\subsection{Measurements of Specific Growth Rate and Chlorophyll a (Chl-a)}

The cyanobacteria isolate was transferred into $100 \mathrm{~mL}$ of BG-11 medium and adjusted to $10^{6} \mathrm{CFU} / \mathrm{mL}$. The culture was incubated under a $12: 12 \mathrm{~h}$ light/dark cycle $(25 \mu \mathrm{mol}$ photon $\mathrm{m}^{-2} / \mathrm{s}$ ) at $25^{\circ} \mathrm{C}$ for 15 days. Eleven milliliters were collected at three-day intervals.

To measure the cyanobacterial growth, $10 \mu \mathrm{L}$ of each sample was dropped on a hemocytometer, and cell numbers were counted under a microscope. The specific growth rate $(\mu)$ was calculated from

$$
\mu=\left(\ln \mathrm{N}_{2}-\ln \mathrm{N}_{1}\right) \times\left(t_{2}-t_{1}\right)^{-1}
$$

where $\mathrm{N}_{1}$ and $\mathrm{N}_{2}$ are the cell numbers at times $t_{1}$ and $t_{2}$, respectively.

To evaluate chl-a content, $10 \mathrm{~mL}$ of the culture was centrifuged at $3600 \times \mathrm{g}$ for $10 \mathrm{~min}$. The pellets were resuspended in $400 \mu \mathrm{L}$ of acetone $(90 \%, v / v)$ and kept at $4{ }^{\circ} \mathrm{C}$ for $24 \mathrm{~h}$ in darkness. After centrifugation at $3600 \times g$ for $30 \mathrm{~min}$, the supernatant was measured for optical density (OD) using a UV-vis spectrophotometer (LUMIstar ${ }^{\circledR}$ Omega, Ortenberg, 
Germany) at 630, 645, 663, and $750 \mathrm{~nm}$, and $90 \%$ acetone solution was used as a blank [100]. The concentration of Chl- $a$ was calculated as

$\left.\operatorname{Chl}-a(\mu \mathrm{g} / \mathrm{mL})=\left[11.64 \times\left(\mathrm{OD}_{663}-\mathrm{OD}_{750}\right)\right)-2.16 \times\left(\mathrm{OD}_{645}-\mathrm{OD}_{750}\right)+10 \times\left(\mathrm{OD}_{630}-\mathrm{OD}_{750}\right)\right] \times 25$

\subsection{Microcystins Production}

To measure the MCs, 10 Microcystis isolates were grown in $30 \mathrm{~mL}$ of BG-11 medium for 15 days, as described above. The culture was centrifuged at $6000 \times g$ for $10 \mathrm{~min}$. The cell pellet and supernatant were collected to measure intracellular MCs (IMCs) and extracellular MCs (EMCs), respectively. The pellet was resuspended in $10 \mathrm{~mL} \mathrm{50 \%} \mathrm{methanol-water}$ solution in order to extract IMCs [101]. Then cell suspension in the methanol solution was sonicated for $10 \mathrm{~min}$, followed by incubation in $50{ }^{\circ} \mathrm{C}$ water for $20 \mathrm{~min}$ [102]. After centrifugation at $10,000 \times g$ for $5 \mathrm{~min}$, the supernatant was filtered through a $0.22 \mu \mathrm{m}$ pore-size polyethersulfone filter (Sartorius, Surrey, UK), and the filtrate was used for IMCs determination. An Abraxis Microcystin Kit (520011) was used to determine IMCs and EMCs concentrations following the manufacturer's instructions. The medium was used as blank. All measurements for MCs were done in duplicate, according to the instructions.

\subsection{Extracellular Polymeric Substances Determination}

Soluble EPS (sEPS) and bound EPS (bEPS) concentrations were determined for protein and carbohydrate content, according to the method described elsewhere [103,104]. Briefly, $30 \mathrm{~mL}$ of cyanobacteria was cultured as described above for 15 days. After centrifugation at $11,550 \times g$ for $15 \mathrm{~min}$, sEPS and bEPS were determined in the supernatant and pellet, respectively. To obtain bEPS, the pellet was resuspended in $5 \mathrm{~mL}$ distilled water and incubated at $45^{\circ} \mathrm{C}$ for $4 \mathrm{~h}$. The mixture was centrifuged at $11,550 \times \mathrm{g}$ for $15 \mathrm{~min}$, and the supernatant containing bEPS was collected. The protein and carbohydrate concentrations of the sEPS and bEPS were quantified by Lowry [105] and phenolsulfuric [106] assays, respectively. The determination was done in triplicate.

Data obtained were analyzed by ANOVA with the post hoc Tukey test using SPSS statistical software version 17.0 for Windows EDU to investigate the significance of EPS content and composition at $p \leq 0.05$.

\subsection{Scum Formation}

Scum formation was determined by observing cell migration to the water surface. Scum formation pictures were illustrated elsewhere $[13,53]$. Cyanobacteria culture was prepared for 7 days, as previously described. After centrifugation at $10,000 \times g$ for $5 \mathrm{~min}$, the pellet was resuspended with $5 \mathrm{~mL}$ of $8 \times$ concentrated BG- 11 medium. The $\mathrm{OD}_{580}$ of the culture was adjusted to 1 , followed by incubation under the constant fluorescent light of $20 \mu \mathrm{mol}$ photons $\mathrm{m}^{-2} / \mathrm{s}$. Scum formation was observed daily for 7 days with the naked eye.

\subsection{Dynamic of MCs Production and Growth}

Microcystis SG03 was cultured in $500 \mathrm{~mL}$ BG-11 medium under the above conditions for 30 days. Thirty-one milliliters was collected every 5 days during the cultivation. To measure cyanobacterial growth, cell numbers from $10 \mu \mathrm{L}$ of each sample were counted under a microscope using a hemocytometer. IMCs and EMCs were determined, as previously described. The experiment was conducted in independent duplicate.

\subsection{Analyses of Cyanotoxins}

Microcystis SG03 was cultured in $300 \mathrm{~mL} \mathrm{BG-11}$ medium for 10 days, as described above. After centrifugation at $\times g$ for $5 \mathrm{~min}$, the pellet was resuspended in $5 \mathrm{~mL} \mathrm{50 \%}$ methanol-water solution. The IMCs were extracted using the same method, as previously described. Cyanotoxins were analyzed by a liquid chromatograph-quadrupole time-of-flight mass spectrometer (LC-QTOF MS) (G6545A, Agilent Technologies, CA, 
USA) [107] equipped with a Zorbax Eclipse plus C18 Rapid Resolution column HD (150 mm length $\times 2.1 \mathrm{~mm}$ inner diameter and particle size $1.8 \mu \mathrm{m}$ ). The column was held at $40{ }^{\circ} \mathrm{C}$ with gradient elution: high-purity water containing $0.1 \%$ formic acid (solvent A) and $11.5 \%$ acetonitrile solution (solvent B). The elution steps were: (1) $70 \% \mathrm{~A}$ and $30 \% \mathrm{~B}$ for $2 \mathrm{~min}$; (2) $5 \%$ A and 95\% B for $14 \mathrm{~min}$; (3) 70\% A and 30\% B for $14.20 \mathrm{~min}$; and (4) $70 \% \mathrm{~A}$ and $30 \% \mathrm{~B}$ for $20 \mathrm{~min}$ at a flow rate of $0.2 \mathrm{~mL} / \mathrm{min}$. The UHPLC system was connected with a quadrupole time-of-flight mass spectrometer, equipped with a Dual Agilent Jet Stream Electrospray Ionization (Dual AJS ESI). The positive electrospray ionization parameters were as follows: gas temp, $325^{\circ} \mathrm{C}$; gas flow, $13 \mathrm{~L} / \mathrm{min}$; nebulizer, $35 \mathrm{psig}$; sheath gas temp., $275^{\circ} \mathrm{C}$; capillary voltage (VCap), $4000 \mathrm{~V}$; nozzle voltage, $2000 \mathrm{~V}$ : fragmentor, $175 \mathrm{~V}$ : skimmer, $65 \mathrm{~V}$; octopole RF peak, $750 \mathrm{~V}$; mass ranges were set at 100-1500 m/z for the TOF-MS scan and the MS/MS experiments. In the auto MS/MS experiment, the collision energies were set at 10,20, and $40 \mathrm{~V}$. Continuous internal calibration was performed during analyses by using the signals at $m / z 121.0509$ (protonated purine) and $m / z 922.0098$ (protonated hexakis ( $1 \mathrm{H}, 1 \mathrm{H}, 3 \mathrm{H}$-tetrafluoropropoxy) phosphazine or HP-921) in positive ionization. Acquisition and data processing were achieved using MassHunter WorkStation LC/MS Data Acquisition software and MassHunter WorkStation Qualitative Analysis Workflows software (version B.08.00, Agilent Technologies, CA, USA), respectively. Identification of the cyanotoxins was based on MS/MS standard: Cayman Chemical Item Number 10445 and available microcystin database Toxinmasslist_com_v15b [62].

Author Contributions: Conceptualization, R.P., O.S. and A.N.; methodology, A.N. and W.R.; validation, R.P. and Y.S.; writing-original draft, A.N.; writing-review and editing, E.K. and R.P. All authors have read and agreed to the published version of the manuscript.

Funding: This research was funded by the Prince of Songkla University (No. SCI6302111S).

Institutional Review Board Statement: Not applicable.

Informed Consent Statement: Not applicable.

Data Availability Statement: All relevant data are within the paper.

Acknowledgments: The authors thank the Division of Biological Science and Faculty of Environmental Management, Prince of Songkla University, Hat Yai, Thailand, for providing the materials and lab-scale system. The authors also appreciate Waraporn Khunpet and Patpicha Khongyod for kindly helping in the water sample collection.

Conflicts of Interest: The authors declare no conflict of interest.

\section{References}

1. Xiao, M.; Willis, A.; Burford, M.A.; Li, M. A meta-analysis comparing cell-division and cell-adhesion in Microcystis colony formation. Harmful Algae 2017, 67, 85-91. [CrossRef]

2. Preece, E.P.; Hardy, F.J.; Moore, B.C.; Bryan, M. A review of microcystin detections in estuarine and marine waters: Environmental implications and human health risk. Harmful Algae 2017, 61, 31-45. [CrossRef]

3. Rastogi, R.P.; Madamwar, D.; Incharoensakdi, A. Bloom dynamics of cyanobacteria and their toxins: Environmental health impacts and mitigation strategies. Front. Microbiol. 2015, 6, 1254. [CrossRef] [PubMed]

4. Rastogi, R.P.; Sinha, R.P.; Incharoensakdi, A. The cyanotoxin-microcystins: Current overview. Rev. Environ. Sci. Bio/Technol. 2014, 13, 215-249. [CrossRef]

5. Sant, C.L.; De Carvalho, L.R.; Fiore, M.F.; Silva-Stenico, M.E.; Lorenzi, A.S.; Rios, F.R.; Konno, K.; Garcia, C.; Lagos, N. Highly toxic Microcystis aeruginosa strain, isolated from São Paulo-Brazil, produce hepatotoxins and paralytic shellfish poison neurotoxins. Neurotox. Res. 2011, 19, 389-402.

6. Podduturi, R.; Schlüter, L.; Liu, T.; Osti, J.A.S.; Moraes, M.d.A.B.; Jørgensen, N.O. Monitoring of saxitoxin production in lakes in Denmark by molecular, chromatographic and microscopic approaches. Harmful Algae 2021, 101, 101966. [CrossRef] [PubMed]

7. Wang, D.-Z.; Zhang, S.-F.; Zhang, Y.; Lin, L. Paralytic shellfish toxin biosynthesis in cyanobacteria and dinoflagellates: A molecular overview. J. Proteom. 2016, 135, 132-140. [CrossRef] [PubMed]

8. Edwards, L.J.; Wilson, K.; Veitch, M.G. An outbreak of paralytic shellfish poisoning in Tasmania. Commun. Dis. Intell. 2018, 42, S2209-S6051.

9. Suleiman, M.; Jelip, J.; Rundi, C.; Chua, T.H. Case report: Paralytic shellfish poisoning in Sabah, Malaysia. Am. J. Trop. Med. Hyg. 2017, 97, 1731-1736. [CrossRef] 
10. WHO. Cyanobacterial Toxins: Microcystin-Lr Guidelines for Drinking-Water Quality; World Health Organization: Geneva, Switzerland, 1998.

11. WHO. Guidelines for Safe Recreational Water Environments: Coastal and Fresh Waters; World Health Organization: Geneva, Switzerland, 2003; Volume 1.

12. Xiao, M.; Li, M.; Reynolds, C.S. Colony formation in the cyanobacterium Microcystis. Biol. Rev. 2018, 93, 1399-1420. [CrossRef]

13. Drugă, B.; Buda, D.-M.; Szekeres, E.; Chiş, C.; Chiş, I.; Sicora, C. The impact of cation concentration on Microcystis (cyanobacteria) scum formation. Sci. Rep. 2019, 9, 1-10.

14. Flemming, H.-C.; Wingender, J.; Szewzyk, U.; Steinberg, P.; Rice, S.A.; Kjelleberg, S. Biofilms: An emergent form of bacterial life. Nat. Rev. Microbiol. 2016, 14, 563. [CrossRef]

15. Naveed, S.; Li, C.; Lu, X.; Chen, S.; Yin, B.; Zhang, C.; Ge, Y. Microalgal extracellular polymeric substances and their interactions with metal (loid) s: A review. Crit. Rev. Environ. Sci. Technol. 2019, 49, 1769-1802. [CrossRef]

16. Paerl, H.W.; Barnard, M.A. Mitigating the global expansion of harmful cyanobacterial blooms: Moving targets in a human-and climatically-altered world. Harmful Algae 2020, 96, 101845. [CrossRef]

17. Metcalf, J.; Banack, S.; Wessel, R.; Lester, M.; Pim, J.; Cassani, J.; Cox, P. Toxin analysis of freshwater cyanobacterial and marine harmful algal blooms on the west coast of Florida and implications for estuarine environments. Neurotox. Res. 2020, 39, 27-35. [CrossRef] [PubMed]

18. Tanabe, Y.; Hodoki, Y.; Sano, T.; Tada, K.; Watanabe, M.M. Adaptation of the freshwater bloom-forming cyanobacterium Microcystis aeruginosa to brackish water is driven by recent horizontal transfer of sucrose genes. Front. Microbiol. 2018, 9, 1150. [CrossRef] [PubMed]

19. Wilhelm, S.W.; Bullerjahn, G.S.; McKay, R.M.L. The complicated and confusing ecology of Microcystis blooms. Mbio 2020, 11, e00529-20. [CrossRef]

20. Donald, D.B.; Bogard, M.J.; Finlay, K.; Leavitt, P.R. Comparative effects of urea, ammonium, and nitrate on phytoplankton abundance, community composition, and toxicity in hypereutrophic freshwaters. Limnol. Oceanogr. 2011, 56, 2161-2175. [CrossRef]

21. Posch, T.; Köster, O.; Salcher, M.M.; Pernthaler, J. Harmful filamentous cyanobacteria favoured by reduced water turnover with lake warming. Nat. Clim. Chang. 2012, 2, 809-813. [CrossRef]

22. Wagner, N.D.; Quach, E.; Buscho, S.; Ricciardelli, A.; Kannan, A.; Naung, S.W.; Phillip, G.; Sheppard, B.; Ferguson, L.; Allen, A. Nitrogen form, concentration, and micronutrient availability affect microcystin production in cyanobacterial blooms. Harmful Algae 2021, 103, 102002. [CrossRef]

23. Sa-Nguansil, S.; Lheknim, V. The occurrence and reproductive status of Yucatan molly Poecilia velifera (Regan, 1914) (Poeciliidae; Cyprinodontiformes): An alien fish invading the Songkhla Lake Basin, Thailand. Aquat. Invasions 2010, 5, 423-430. [CrossRef]

24. Sakai, K.; Lheknim, V. Two new species of the genera Neocallichirus and Wolffogebia (Decapoda, Pleocyemata) from Thale Sap Songkhla, Songkhla Lagoon System, Songkhla Province, Thailand. Crustaceana 2014, 87, 91-100. [CrossRef]

25. Rattanama, K.; Pattaratumrong, M.S.; Towatana, P.; Wongkamhaeng, K. Three new records of gammarid a mphipod in Songkhla Lake, Thailand. Trop. Life Sci. Res. 2016, 27, 53. [CrossRef]

26. Chesoh, S.; Lim, A.; Tongkumchum, P. Trend of water quality and model for forecasting eutrophication occurrence in Songkhla Lake, Thailand. In Proceedings of the Taal 2007: The 12th World Lake Conference, Jaipur, India, 28 October-2 November 2007; pp. 834-839.

27. Suwanidcharoen, S.; Liengcharernsit, W. Development of phytoplankton model with application to Songkhla Lake, Thailand. Lowl. Technol. Int. 2012, 14, 50-59.

28. Pham, T.-L.; Tran, T.H.Y.; Shimizu, K.; Li, Q.; Utsumi, M. Toxic cyanobacteria and microcystin dynamics in a tropical reservoir: Assessing the influence of environmental variables. Environ. Sci. Pollut. Res. 2020, 1-14. [CrossRef]

29. Huisman, J.; Codd, G.A.; Paerl, H.W.; Ibelings, B.W.; Verspagen, J.M.; Visser, P.M. Cyanobacterial blooms. Nat. Rev. Microbiol. 2018, 16, 471-483. [CrossRef]

30. Massey, I.Y.; Al Osman, M.; Yang, F. An overview on cyanobacterial blooms and toxins production: Their occurrence and influencing factors. Toxin Rev. 2020, 1-21. [CrossRef]

31. Tillett, D.; Dittmann, E.; Erhard, M.; Von Döhren, H.; Börner, T.; Neilan, B.A. Structural organization of microcystin biosynthesis in Microcystis aeruginosa PCC7806: An integrated peptide-polyketide synthetase system. Chem. Biol. 2000, 7, 753-764. [CrossRef]

32. Feng, H.; Clara, T.; Huang, F.; Wei, J.; Yang, F. Identification and characterization of the dominant Microcystis sp. cyanobacteria detected in Lake Dong Ting, China. J. Toxicol. Environ. Health Part A 2019, 82, 1143-1150. [CrossRef]

33. Lee, J.; Choi, J.; Fatka, M.; Swanner, E.; Ikuma, K.; Liang, X.; Leung, T.; Howe, A. Improved detection of mcyA genes and their phylogenetic origins in harmful algal blooms. Water Res. 2020, 176, 115730. [CrossRef]

34. Hu, C.; Rea, C.; Yu, Z.; Lee, J. Relative importance of Microcystis abundance and diversity in determining microcystin dynamics in Lake Erie coastal wetland and downstream beach water. J. Appl. Microbiol. 2016, 120, 138-151. [CrossRef] [PubMed]

35. Hisbergues, M.; Christiansen, G.; Rouhiainen, L.; Sivonen, K.; Börner, T. PCR-based identification of microcystin-producing genotypes of different cyanobacterial genera. Arch. Microbiol. 2003, 180, 402-410. [CrossRef] [PubMed]

36. Picardo, M.; Filatova, D.; Nunez, O.; Farré, M. Recent advances in the detection of natural toxins in freshwater environments. TrAC Trends Anal. Chem. 2019, 112, 75-86. [CrossRef] 
37. Christiansen, G.; Molitor, C.; Philmus, B.; Kurmayer, R. Nontoxic strains of cyanobacteria are the result of major gene deletion events induced by a transposable element. Mol. Biol. Evol. 2008, 25, 1695-1704. [CrossRef]

38. Gkelis, S.; Zaoutsos, N. Cyanotoxin occurrence and potentially toxin producing cyanobacteria in freshwaters of Greece: A multi-disciplinary approach. Toxicon 2014, 78, 1-9. [CrossRef] [PubMed]

39. Kellmann, R.; Mihali, T.K.; Jeon, Y.J.; Pickford, R.; Pomati, F.; Neilan, B.A. Biosynthetic intermediate analysis and functional homology reveal a saxitoxin gene cluster in cyanobacteria. Appl. Environ. Microbiol. 2008, 74, 4044-4053. [CrossRef]

40. Wiese, M.; D'agostino, P.M.; Mihali, T.K.; Moffitt, M.C.; Neilan, B.A. Neurotoxic alkaloids: Saxitoxin and its analogs. Mar. Drugs 2010, 8, 2185-2211. [CrossRef] [PubMed]

41. Akbar, M.A.; Mohd Yusof, N.Y.; Tahir, N.I.; Ahmad, A.; Usup, G.; Sahrani, F.K.; Bunawan, H. Biosynthesis of saxitoxin in marine dinoflagellates: An omics perspective. Mar. Drugs 2020, 18, 103. [CrossRef] [PubMed]

42. Pereyra, J.P.; D'Agostino, P.M.; Mazmouz, R.; Woodhouse, J.N.; Pickford, R.; Jameson, I.; Neilan, B.A. Molecular and morphological survey of saxitoxin-producing cyanobacterium Dolichospermum circinale (Anabaena circinalis) isolated from geographically distinct regions of Australia. Toxicon 2017, 138, 68-77. [CrossRef] [PubMed]

43. Chorus, I.; Welker, M. Toxic Cyanobacteria in Water: A Guide to Their Public Health Consequences, Monitoring and Management; CRC Press: London, UK, 2021.

44. Yang, Y.; Hou, J.; Wang, P.; Wang, C.; Wang, X.; You, G. Influence of extracellular polymeric substances on cell-NPs heteroaggregation process and toxicity of cerium dioxide NPs to Microcystis aeruginosa. Environ. Pollut. 2018, 242, $1206-1216$. [CrossRef]

45. Blanco, Y.; Rivas, L.A.; González-Toril, E.; Ruiz-Bermejo, M.; Moreno-Paz, M.; Parro, V.; Palacín, A.; Aguilera, Á.; Puente-Sánchez, F. Environmental parameters, and not phylogeny, determine the composition of extracellular polymeric substances in microbial mats from extreme environments. Sci. Total Environ. 2019, 650, 384-393. [CrossRef] [PubMed]

46. Xiao, M.; Li, M.; Duan, P.; Qu, Z.; Wu, H. Insights into the relationship between colony formation and extracellular polymeric substances (EPS) composition of the cyanobacterium Microcystis spp. Harmful Algae 2019, 83, 34-41. [CrossRef]

47. Chen, M.; Tian, L.-L.; Ren, C.-Y.; Xu, C.-Y.; Wang, Y.-Y.; Li, L. Extracellular polysaccharide synthesis in a bloom-forming strain of Microcystis aeruginosa: Implications for colonization and buoyancy. Sci. Rep. 2019, 9, 1-11. [CrossRef] [PubMed]

48. Sun, F.; Zhang, H.; Qian, A.; Yu, H.; Xu, C.; Pan, R.; Shi, Y. The influence of extracellular polymeric substances on the coagulation process of cyanobacteria. Sci. Total Environ. 2020, 720, 137573. [CrossRef]

49. Holland, A.; Kinnear, S. Interpreting the possible ecological role (s) of cyanotoxins: Compounds for competitive advantage and/or physiological aide? Mar. Drugs 2013, 11, 2239-2258. [CrossRef] [PubMed]

50. Liu, L.; Qin, B.; Zhang, Y.; Zhu, G.; Gao, G.; Huang, Q.; Yao, X. Extraction and characterization of bound extracellular polymeric substances from cultured pure cyanobacterium (Microcystis wesenbergii). J. Environ. Sci. 2014, 26, 1725-1732. [CrossRef] [PubMed]

51. Li, X.; Luo, K.; Ren, J.; Wang, X.; Mu, Q.; Fan, W. Characterisation of extracellular polymeric substances from different cyanobacterial species and their influence on biocalcification processes. Environ. Chem. 2017, 14, 254-265. [CrossRef]

52. Yamamoto, Y.; Shiah, F.-K.; Chen, Y.-L. Importance of large colony formation in bloom-forming cyanobacteria to dominate in eutrophic ponds. Ann. Limnol. Int. J. Limnol. 2011, 47, 167-173. [CrossRef]

53. Dervaux, J.; Mejean, A.; Brunet, P. Irreversible collective migration of cyanobacteria in eutrophic conditions. PLoS ONE 2015, 10, e0120906. [CrossRef] [PubMed]

54. Medrano, E.A.; Uittenbogaard, R.; Van De Wiel, B.; Pires, L.D.; Clercx, H. An alternative explanation for cyanobacterial scum formation and persistence by oxygenic photosynthesis. Harmful Algae 2016, 60, 27-35. [CrossRef] [PubMed]

55. Guo, Y.C.; Lee, A.K.; Yates, R.S.; Liang, S.; Rochelle, P.A. Analysis of microcystins in drinking water by ELISA and LC/MS/MS. J. Am. Water Work. Assoc. 2017, 109, 13-25. [CrossRef]

56. Botha, C.J.; Laver, P.; Singo, A.; Venter, E.; Ferreira, G.C.H.; Rösemann, M.; Myburgh, J.G. Evaluation of a Norwegian-developed ELISA to determine microcystin concentrations in fresh water. Water Supply 2019, 19, 743-752. [CrossRef]

57. Fischer, W.J.; Garthwaite, I.; Miles, C.O.; Ross, K.M.; Aggen, J.B.; Chamberlin, A.R.; Towers, N.R.; Dietrich, D.R. Congenerindependent immunoassay for microcystins and nodularins. Environ. Sci. Technol. 2001, 35, 4849-4856. [CrossRef] [PubMed]

58. Song, L.; Sano, T.; Li, R.; Watanabe, M.M.; Liu, Y.; Kaya, K. Microcystin production of Microcystis viridis (cyanobacteria) under different culture conditions. Phycol. Res. 1998, 46, 19-23. [CrossRef]

59. Long, B.M.; Jones, G.J.; Orr, P.T. Cellular microcystin content in N-limited Microcystis aeruginosa can be predicted from growth rate. Appl. Environ. Microbiol. 2001, 67, 278-283. [CrossRef]

60. Makower, A.K.; Schuurmans, J.M.; Groth, D.; Zilliges, Y.; Matthijs, H.C.; Dittmann, E. Transcriptomics-aided dissection of the intracellular and extracellular roles of microcystin in Microcystis aeruginosa PCC 7806. Appl. Environ. Microbiol. 2015, 81, 544-554. [CrossRef] [PubMed]

61. Beversdorf, L.J.; Miller, T.R.; McMahon, K.D. Long-term monitoring reveals carbon-nitrogen metabolism key to microcystin production in eutrophic lakes. Front. Microbiol. 2015, 6, 456. [CrossRef]

62. Miles, C. Toxinmasslist COM v15b [Data set]. Unpublished Work, 2018; Volume 604. Available online: https://www.researchgate. net/publication/324039408_Toxinmasslist_COM_v15b?channel=doi\&linkId=5aba5f4caca2728f4fa3ed38\&showFulltext=true (accessed on 29 July 2021).

63. Harke, M.J.; Steffen, M.M.; Gobler, C.J.; Otten, T.G.; Wilhelm, S.W.; Wood, S.A.; Paerl, H.W. A review of the global ecology, genomics, and biogeography of the toxic cyanobacterium, Microcystis spp. Harmful Algae 2016, 54, 4-20. [CrossRef] [PubMed] 
64. Yang, Z.; Liu, Y.; Ge, J.; Wang, W.; Chen, Y.; Montagnes, D. Aggregate formation and polysaccharide content of Chlorella pyrenoidosa Chick (Chlorophyta) in response to simulated nutrient stress. Bioresour. Technol. 2010, 101, 8336-8341. [CrossRef] [PubMed]

65. Sun, F.; Pan, R.; Qian, A.; Cong, H.; Lamas-Samanamud, G. Consideration on the Water Contamination of Cyanobacterial Extracellular Polymeric Substances (EPS). J. Environ. Sci. Allied Res. 2017, 1, 19-24.

66. Pham, T.-L.; Utsumi, M. An overview of the accumulation of microcystins in aquatic ecosystems. J. Environ. Manag. 2018, 213, 520-529. [CrossRef]

67. Wiedner, C.; Visser, P.M.; Fastner, J.; Metcalf, J.S.; Codd, G.A.; Mur, L.R. Effects of light on the microcystin content of Microcystis strain PCC 7806. Appl. Environ. Microbiol. 2003, 69, 1475-1481. [CrossRef] [PubMed]

68. Zhou, Y.; Li, X.; Xia, Q.; Dai, R. Transcriptomic survey on the microcystins production and growth of Microcystis aeruginosa under nitrogen starvation. Sci. Total Environ. 2020, 700, 134501. [CrossRef]

69. Peng, G.; Lin, S.; Fan, Z.; Wang, X. Transcriptional and physiological responses to nutrient loading on toxin formation and photosynthesis in Microcystis aeruginosa FACHB-905. Toxins 2017, 9, 168. [CrossRef] [PubMed]

70. Jüttner, F.; Lüthi, H. Topology and enhanced toxicity of bound microcystins in Microcystis PCC 7806. Toxicon 2008, 51, 388-397. [CrossRef]

71. Yeung, A.C.; D'Agostino, P.M.; Poljak, A.; McDonald, J.; Bligh, M.W.; Waite, T.D.; Neilan, B.A. Physiological and proteomic responses of continuous cultures of Microcystis aeruginosa PCC 7806 to changes in iron bioavailability and growth rate. Appl. Environ. Microbiol. 2016, 82, 5918-5929. [CrossRef] [PubMed]

72. Bouaïcha, N.; Miles, C.O.; Beach, D.G.; Labidi, Z.; Djabri, A.; Benayache, N.Y.; Nguyen-Quang, T. Structural diversity, characterization and toxicology of microcystins. Toxins 2019, 11, 714. [CrossRef] [PubMed]

73. Foss, A.J.; Miles, C.O.; Wilkins, A.L.; Rise, F.; Trovik, K.W.; Cieslik, K.; Aubel, M.T. Analysis of total microcystins and nodularins by oxidative cleavage of their ADMAdda, DMAdda, and Adda moieties. Anal. Chim. Acta X 2020, 6, 100060.

74. Puddick, J.; Prinsep, M.R.; Wood, S.A.; Cary, S.C.; Hamilton, D.P.; Holland, P.T. Further characterization of glycine-containing microcystins from the McMurdo dry valleys of Antarctica. Toxins 2015, 7, 493-515. [CrossRef] [PubMed]

75. Sivonen, K.; Namikoshi, M.; Evans, W.R.; Fardig, M.; Carmichael, W.W.; Rinehart, K.L. Three new microcystins, cyclic heptapeptide hepatotoxins, from Nostoc sp. strain 152. Chem. Res. Toxicol. 1992, 5, 464-469. [CrossRef] [PubMed]

76. Namikoshi, M.; Sun, F.; Choi, B.W.; Rinehart, K.L.; Carmichael, W.W.; Evans, W.R.; Beasley, V.R. Seven more microcystins from homer lake cells: Application of the general method for structure assignment of peptides containing Alpha, Beta-dehydroamino acid unit (s). J. Org. Chem. 1995, 60, 3671-3679. [CrossRef]

77. Bouhaddada, R.; Nélieu, S.; Nasri, H.; Delarue, G.; Bouaïcha, N. High diversity of microcystins in a Microcystis bloom from an Algerian lake. Environ. Pollut. 2016, 216, 836-844. [CrossRef] [PubMed]

78. Harada, K.-I.; Murata, H.; Qiang, Z.; Suzuki, M.; Kondo, F. Mass spectrometric screening method for microcystins in cyanobacteria. Toxicon 1996, 34, 701-710. [CrossRef]

79. Borges, H.; Branco, L.; Martins, M.; Lima, C.; Barbosa, P.; Lira, G.; Bittencourt-Oliveira, M.; Molica, R. Cyanotoxin production and phylogeny of benthic cyanobacterial strains isolated from the northeast of Brazil. Harmful Algae 2015, 43, 46-57. [CrossRef]

80. Harland, F.; Wood, S.A.; Broady, P.; Williamson, W.; Gaw, S. Changes in saxitoxin-production through growth phases in the metaphytic cyanobacterium Scytonema cf. crispum. Toxicon 2015, 103, 74-79. [CrossRef]

81. Mesquita, M.C.; Lürling, M.; Dorr, F.; Pinto, E.; Marinho, M.M. Combined effect of light and temperature on the production of saxitoxins in Cylindrospermopsis raciborskii strains. Toxins 2019, 11, 38. [CrossRef]

82. Moustaka-Gouni, M.; Hiskia, A.; Genitsaris, S.; Katsiapi, M.; Manolidi, K.; Zervou, S.-K.; Christophoridis, C.; Triantis, T.M.; Kaloudis, T.; Orfanidis, S. First report of Aphanizomenon favaloroi occurrence in Europe associated with saxitoxins and a massive fish kill in Lake Vistonis, Greece. Mar. Freshw. Res. 2017, 68, 793-800. [CrossRef]

83. Smith, Z.J.; Martin, R.M.; Wei, B.; Wilhelm, S.W.; Boyer, G.L. Spatial and temporal variation in paralytic shellfish toxin production by benthic Microseira (Lyngbya) wollei in a freshwater New York lake. Toxins 2019, 11, 44. [CrossRef] [PubMed]

84. Trainer, V.L.; Hardy, F.J. Integrative monitoring of marine and freshwater harmful algae in Washington State for public health protection. Toxins 2015, 7, 1206-1234. [CrossRef]

85. Yunes, J.S.; De La Rocha, S.; Giroldo, D.; Silveira, S.B.d.; Comin, R.; Bicho, M.d.S.; Melcher, S.S.; Sant'anna, C.L.; Vieira, A.A.H. Release of carbohydrates and proteins by a subtropical strain of Raphidiopsis brookii (cyanobacteria) able to produce saxitoxin at three nitrate concentrations. J. Phycol. 2009, 45, 585-591. [CrossRef] [PubMed]

86. Raposo, M.I.; Gomes, M.T.S.; Botelho, M.J.; Rudnitskaya, A. Paralytic shellfish toxins (PST)-transforming enzymes: A review. Toxins 2020, 12, 344. [CrossRef]

87. Garcia, C.; del Carmen Bravo, M.; Lagos, M.; Lagos, N. Paralytic shellfish poisoning: Post-mortem analysis of tissue and body fluid samples from human victims in the Patagonia fjords. Toxicon 2004, 43, 149-158. [CrossRef]

88. Christensen, V.G.; Maki, R.P.; Stelzer, E.A.; Norland, J.E.; Khan, E. Phytoplankton community and algal toxicity at a recurring bloom in Sullivan Bay, Kabetogama Lake, Minnesota, USA. Sci. Rep. 2019, 9, 1-11.

89. Prommana, R.; Peerapornpisal, Y.; Whangchai, N.; Morrison, L.F.; Metcalf, J.S.; Ruangyuttikarn, W.; Towprom, A.; Codd, G.A. Microcystins in cyanobacterial blooms from two freshwater prawn (Macrobrachium rosenbergii) ponds in Northern Thailand. Sci. Asia 2006, 32, 365-370. [CrossRef] 
90. Ruangrit, K.; Whangchai, N.; Pekkoh, J.; Ruangyuttikarn, W.; Peerapornpisal, Y. First report on microcystins contamination in giant freshwater prawn (Macrobrachium rosenbergii) and nile tilapia (Tilapia nilotica) cultured in earthen ponds. Int. J. Agric. Biol. 2011, 13, 1-4.

91. Whangchai, N.; Wanno, S.; Gutierrez, R.; Kannika, K.; Promna, R.; Iwami, N.; Itayama, T. Accumulation of microcystins in water and economic fish in Phayao Lake, and fish ponds along the Ing River tributary in Chiang Rai, Thailand. Agric. Sci. $2013,4,52$. [CrossRef]

92. Ruangsomboon, S.; Yongmanitchai, W.; Taveekijakarn, P.; Ganmanee, M. Cyanobacterial composition and microcystin accumulation in catfish pond. Chiang Mai J. Sci. 2014, 41, 27-38.

93. Somdee, T.; Kaewkhiaw, K.; Somdee, A. Detection of toxic cyanobacteria and quantifi cation of microcystins in four recreational water reservoirs in Khon Kaen, Thailand. Asia-Pac. J. Sci. Technol. 2013, 18, 1-8.

94. Pongswat, S.; Suphan, S. Toxic Algae as a Component of Phytoplankton in Irrigation Canals (Thailand). Chiang Mai J. Sci. 2015, $42,560-577$.

95. Kungsuwan, A.; Arakawa, O.; Promdet, M.; Onoue, Y. Occurrence of paralytic shellfish poisons in Thai freshwater puffers. Toxicon 1997, 35, 1341-1346. [CrossRef]

96. Sato, S.; Kodama, M.; Ogata, T.; Saitanu, K.; Furuya, M.; Hirayama, K.; Kakinuma, K. Saxitoxin as a toxic principle of a freshwater puffer, Tetraodon fangi, in Thailand. Toxicon 1997, 35, 137-140. [CrossRef]

97. Belcher, H.; Swale, E. Culturing Algae: A Guide for Schools and Colleges; Institute of Terrestrial Ecology: Cambridge, UK, 1982.

98. Ballot, A.; Fastner, J.; Wiedner, C. Paralytic shellfish poisoning toxin-producing cyanobacterium Aphanizomenon gracile in northeast Germany. Appl. Environ. Microbiol. 2010, 76, 1173-1180. [CrossRef] [PubMed]

99. Jungblut, A.D.; Hawes, I.; Mountfort, D.; Hitzfeld, B.; Dietrich, D.R.; Burns, B.P.; Neilan, B.A. Diversity within cyanobacterial mat communities in variable salinity meltwater ponds of McMurdo Ice Shelf, Antarctica. Environ. Microbiol. 2005, 7, 519-529. [CrossRef] [PubMed]

100. Arvola, L. Spectrophotometric determination of chlorophyll a and phaeopigments in ethanol extractions. Ann. Bot. Fenn. 1981, $18,221-227$.

101. Dai, R.; Liu, H.; Qu, J.; Zhao, X.; Hou, Y. Effects of amino acids on microcystin production of the Microcystis aeruginosa. J. Hazard. Mater. 2009, 161, 730-736. [CrossRef] [PubMed]

102. Gkelis, S.; Tussy, P.F.; Zaoutsos, N. Isolation and preliminary characterization of cyanobacteria strains from freshwaters of Greece. Open Life Sci. 2015, 10, 52-60. [CrossRef]

103. Jittawuttipoka, T.; Planchon, M.; Spalla, O.; Benzerara, K.; Guyot, F.; Cassier-Chauvat, C.; Chauvat, F. Multidisciplinary evidences that Synechocystis PCC6803 exopolysaccharides operate in cell sedimentation and protection against salt and metal stresses. PLOS ONE 2013, 8, e55564.

104. Yang, Z.; Kong, F.; Shi, X.; Zhang, M.; Xing, P.; Cao, H. Changes in the morphology and polysaccharide content of Microcystis aeruginosa (Cyanobacteria) during flagellate grazing. J. Phycol. 2008, 44, 716-720. [CrossRef]

105. Dubois, M.; Gilles, K.A.; Hamilton, J.K.; Rebers, P.t.; Smith, F. Colorimetric method for determination of sugars and related substances. Anal. Chem. 1956, 28, 350-356. [CrossRef]

106. Peterson, G.L. A simplification of the protein assay method of Lowry et al. which is more generally applicable. Anal. Biochem. 1977, 83, 346-356. [CrossRef]

107. Dos Anjos, F.M.; do Carmo Bittencourt-Oliveira, M.; Zajac, M.P.; Hiller, S.; Christian, B.; Erler, K.; Luckas, B.; Pinto, E. Detection of harmful cyanobacteria and their toxins by both PCR amplification and LC-MS during a bloom event. Toxicon 2006, 48, 239-245. [CrossRef] [PubMed] 